https://helda.helsinki.fi

\title{
Sustainability driven new business models in wood construction towards 2030
}

\section{Toppinen, Anne Maarit Kristiina}

Springer

2018-01-29

Toppinen , A M K , Autio , M M , Sauru , M E \& Berghäll , S A 2018 , Sustainability driven new business models in wood construction towards 2030 . in W Leah Filho, I Borges de Lima , D-M Pociovalisteanu \& P Brito (eds), Towards a sustainbale bioeconomy: Principles, Challenges and Perspectives . Springer World Sustainability Series, Springer, Cham , pp. 499-510 . https://doi.org/10.1007/978-3-319-73028-8_25

http://hdl.handle.net/10138/310148

https://doi.org/10.1007/978-3-319-73028-8_25

unspecified

acceptedVersion

Downloaded from Helda, University of Helsinki institutional repository.

This is an electronic reprint of the original article.

This reprint may differ from the original in pagination and typographic detail.

Please cite the original version. 
Please note that this is a so-called personal version (author's manuscript as accepted for publishing after the review process but prior to final layout and copyediting) of the article: Toppinen, Anne, Autio, Minna, Sauru, Miska \& Berghäll, Sami (2018) Sustainability driven new business models in the wood construction towards 2030. In: Towards a Sustainable Bioeconomy: Principles, Challenges and Perspectives. Walter Leal Filho, Diana Mihaela Pociovălișteanu, Paulo Roberto Borges de Brito, Ismar Borges de Lima (eds.). Springer World Sustainability Series, 499-516.

\title{
Sustainability driven new business models in wood construction towards 2030
}

\author{
Toppinen, A. ${ }^{1,}$ Autio, $M .{ }^{2}$ Sauru, $M .{ }^{1} \&$ Berghäll, $S .{ }^{1}$
}

1) University of Helsinki, Department of Forest Sciences, Finland, ${ }^{*}$ Corresponding author

2) University of Helsinki, Department of Economics and Management, Finland

\begin{abstract}
In the transition towards a renewable material based bioeconomy in Europe, there is growing interest in wooden multistory construction (WMC) as a sustainable housing solution. In this paper, the changing WMC business, and the involved value networks towards 2030, are analysed based on service business model literature and focusing also on consumer driven models. Methodologically the study uses a three round Delphi process focusing on Finland as a country where national bioeconomy strategy specifically acknowledges wood based construction. Based on our results, supporting bioeconomy strategy with the use of renewable materials and addressing indoor air quality concerns, seem to be primary reasons for the use of wood. This happens instead of enhancing intrinsic motivation towards sustainable bioeconomy as such. Therefore, transforming business models towards sustainability calls for strengthening positive image of wood construction industry especially among largely neglected stakeholder group, residents. In order to achieve business model development, the industry needs to strengthen orchestration of partner networks and capabilities, by including not only new co-creators as a part of actor-to-actor network, but also residents as end-users.
\end{abstract}

\section{Introduction and purpose}

Sustainability is a key conceptual argument in favour of the general acceptability of bioeconomy as such. However, new sustainability driven innovations are called for in order to renew the traditional sectors of economy into a truly new bioeconomy. The rise of wooden multistory construction (WMC) is currently the most evident new business opportunity in the Nordic countries, especially as it has not faced sustainability related critical voices. Also according to Bosman and Rotmans (2016), the Finnish national level strategy towards bioeconomy is focusing on wooden buildings and construction materials. However, there is a lack of business model related innovations (or business model research) in this dimension of the bioeconomy - especially from service development point of view (Hansen 2016). This fact emphasizes the need to better understand both how and where value is created but also the roles various parties have within and outside the firm have in this value creation.

According to Bourdeau (1999, p. 364), the main challenge of construction business is "to transform the demand for sustainable development into an opportunity, to create and access new markets, and to innovative responses which satisfy traditional industry demands and the new societal demands for sustainable development." As a part of the rise of the green building concept, there is a growing recognition of wood construction. This includes also the use of hybrid structures (e.g. combinations of wood and steel; wood and concrete) (e.g. Wang et al. 2014). According to a recent systematic review on the drivers of green building, Darko et al. (2017) found that the demand, and willingness 
of clients/customers, determines the extent that green building systems are developed. Häkkinen and Belloni (2011) link this customer demand to issues such as knowledge of the issue, supply of solutions, methods, value, and costs.

Also in building competitive a advantage for themselves, the construction business has merely focused on cost-effectiveness (Harris \& Halkett 2007) and emphasised a view based on the importance of creating tangible objects - buildings. Overall, the construction industry is not perceived to be an innovative business in meeting consumer expectations or transforming their core business models into consumer-driven ones. However, the industry has started to recognize consumers' diversifying preferences. For instance, pro-environmental behaviour (Hu et al. 2013), has resulted in creating more customer-centric culture (e.g., Killip, 2013). Recently, studies on consumer's sustainability related choices towards green building have started to gain more ground (e.g. Luo et al. 2017; Gold \& Rubik 2009; Hoffman \& Henn 2008; Holopainen et al. 2014; Hoibo et al. 2015).

Previous literature on business models in construction sector is quite extensive (see a review by Mokhlesian and Holmen 2012). However, regarding the specific viewpoint of renewable wood based construction, with the exception of Brege et al. (2014), Lessing and Brege (2015) and Höök et al. (2015), there is a very scarce literature combining business model perspective to the wood building sector as a holistic view on how companies do business. In order to differentiate between strategic and operational effectiveness, Brege et al. (2014) focused on market position, system offering and operational platform as key business model blocks in the Swedish house-building sector. Using a case study approach, they found five business model elements to be important for WMC: prefabrication mode, changing actor roles in the building process, end-user segments, system augmentation and the use of complementary resources. In a follow-up study on two case companies, Lessing and Brege (2015) found that the use of end-customer knowledge to identify target segment, development of an offering, and sequentially increasing control over the production and value chain, would be a recipe for success in business development. In a conceptual study by Pelli (2016), the use of a ServiceDominant-Logic perspective (SDL, Vargo and Lusch 2016) resulted in buildings being perceived as service platforms, but also that built environment was integrated with the natural environment. In Toppinen et al. (2017), the importance of the issues related to sustainable development was perceived to play an increasing role in the Nordic WMC market because the future consumers and end-users are likely to be increasingly driven by the aims of finding sustainable lifestyle based solutions for their housing.

In this paper, we combine the business model literature to the SDL as a platform to analyze the changing WMC business and the involved value networks towards 2030. Methodologically the study uses three round Delphi process conducted in 2016-2017 among construction value chain professionals in Finland, but also by drawing from the expertise existing in the European pioneering WMC country of Sweden.

\section{Conceptual background}

Teece (2010) describes a company's business model as tool describing how it converts resources and capabilities into economic output, i.e. creates, captures and delivers value. Business model and company strategy are two constructs that bear close connection, and some scholar have even used the terms interchangeably (Magretta 2002). In a seminal paper Osterwalder et al. (2005) the conceptualization of business model has nine elements under four pillars: product, customer interface, infrastructure management and financial aspects, and are in empirical world approached using tools like business model canvas. Furthermore, literature on consumer-driven business models (e.g. Anderson-Connell et al. 2002; Pynnönen 2008; Pynnönen et al. 2012, Pels and Sheth 2017) is a scarce, yet, there some studies which have focused on consumer demand challenges within a business 
strategy (e.g. monitoring consumer needs, logistical solution on the company level). Yet, seeing consumers as active agents interacting and communicating with businesses by contributing to the business model development has not been paid much attention in scholarly literature.

According to Vargo and Lusch (2008), Service Dominant Logic essentially builds upon "the application of competences for the benefit of customers; customers are operant resources, rather than operand resources, and they can contribute as value co-creators to the service process". For the S-D logic to renew the traditional industries (like construction or wood industry both are) would require the users and consumers to be more actively involved in the development process of the products or services (see also Storbacka et al. 2012). To understand why, we need to delve more deeply into the concepts of value, value creation and the context of this creation (namely networks) we need a comprehensive view of the institutional service ecosystems. The following describes the approach more thoroughly.

Service dominant logic (Vargo and Lusch, 2004; 2016; 2017) makes an effort into reframing the model of economic exchange. The core is that we should move away from seeing economic exchange as an exchange of products or product-like services ${ }^{1}$. Instead one should dive a little further into the economic process and asking: what is at the core of the "service" this exchange provides for the parties - ie. what benefits the engagement provides (Vargo and Lusch, 2016). Vargo and Lusch (ibid.) argue, that instead of competitive advantage one should what "strategic benefit" the exchange provides to the "actors" involved (ibid). Thus, in SDL, exchange is based on the intangible value the actors get from the setting. Therefore, value is not created by a producer of good but co-created in the consumption of a service. Products are value carriers but actual value is "phenomenologically" defined by each of the partners for themselves (Vargo and Lusch, 2004). However, while value is defined by each actor, the actor-to-actor (AtoA) relationship is the setting in which value is created (Vargo and Lusch, 2016). As value is created in an exchange setting Vargo and Lusch (2004) see it as a co-creation process (also other scholars e.g. Edvardson \& al., 2011; Payne \& al, 2008). In line with the classic Hunt and Morgan (1995) Resource Advantage Theory of Competition, value is born out of the resources and capabilities of the exchange partners benefitting the other.

The previous view of value creation is therefore like a process of value facilitation. However, while value is co-created it is also framed by the context in which this exchange happens (Chandler and Vargo, 2011). This is because the resources and capabilities exist in a network that itself provides the context of this AtoA relationship. Thus, also the values, norms and belief systems of the exchange setting have an impact on the value co-creation. Vargo (2016) uses the term institutions (referring to social institutions) to describe the setting. Therefore while value is co-created in AtoA exchange it is conditioned by the network where it happens. Thus, as institution are relatively stable in their way of operation (social institutions) Vargo and Lusch see institutional changes as the only path to radical innovations (Vargo and Lusch, 2016). For the WMC setting, we see that radical systemic changes fit into this definition of innovations. The core result of this logical path is that new modes of operations often require not only new capabilities and resources but also new networks where the social institutions are different from the established ones facilitating new modes of operations and adoption of new ideas.

In a systematic literature review, Mokhlesian and Holmen (2012) analysed 38 studies on business models for the greening construction sector using the nine elements from Osterwalder et al al. (2005).

\footnotetext{
${ }^{1}$ Vargo and Lusch (2017) argue that due to Adam Smiths' concentration on export as a means for national creation of wealth the economic models have excluded the value of products as instruments of service. This has given birth to the miss-conception of high-value added industrial products and low productivity services. Thus, the phenomenon SDL is discussing a far more fundamental phenomenon than a goods dominant logic of thinking might at first view it to be.
} 
They found that the most important elements that facilitate change towards green construction practices (falling under the pillar infrastructure management) are capability, partner networks and value configuration. Based on this, we will also focus in our empirical analysis on these elements. However, it is important to note that these elements are not only interconnected with each other but also the other six elements present in Osterwalder et al. (2005) model (see Table 1).

Table 1. Infrastructure management part of business model by Osterwalder et al. (2005)

\begin{tabular}{|l|l|}
\hline Business model block & Description \\
\hline Value Configuration & $\begin{array}{l}\text { Describes the arrangement of activities and } \\
\text { resources. }\end{array}$ \\
\hline $\begin{array}{l}\text { Core Competency/ } \\
\text { Capability }\end{array}$ & $\begin{array}{l}\text { Outlines the competencies necessary to execute } \\
\text { the company's business model }\end{array}$ \\
\hline $\begin{array}{l}\text { Partner Network } \\
\text { Management }\end{array}$ & $\begin{array}{l}\text { Portrays the network of cooperative agreements } \\
\text { with other companies necessary to efficiently offer } \\
\text { and commercialize value }\end{array}$ \\
\hline
\end{tabular}

\section{Data and methodology}

The data was collected with a three stage expert Delphi study during 2016-17. The Delphi was used to elicitate participant perceptions on sustainable business model innovations related to WMC. The core for using the Delphi method is that, bringing (geographically) dispersed experts together, and bringing up a personal viewpoint without group pressure due to anonymity, are seen as advantages of the Delphi method (see for example Landeta 2006). Therefore, the phenomenon being a new developing subject, the Delphi was seen as advantageous in gauging the subject with relative depth but balanced by unrestricted modes of response possibilities for the respondents.

Our dissensus-based Delphi approach consisted of both thematic interviews (Rounds 1 and 3, altogether $18+16$ interviews) and an online survey (Round 2, 17 respondents). Figure 1 depicts the Delphi process. The panelists involved in our study were of Finnish and Swedish origin, and they were required to have in-depth knowledge of the usage of wood in multistory construction in the Nordic region. Due to emphasis on the market and business aspects, this study excluded for example consultants and architects with purely technical background or representatives from end-users. Also omitting experts outside wood construction residents can be seen as a limitation, but in general this types of qualitative studies are limited in the number of respondents that can be included without the material growing too exponential amounts to be analyzed. Although we made an effort to ensure sufficient and diverse expertise in the panel, there were some difficulties in finding experts for the personal interviews with the targeted high level of professional background. The Swedish data was a fewer as it was predominantly used to benchmark the Finnish perspectives. The composition of panel based on the respondent background and professional expertise is given in an Appendix. 


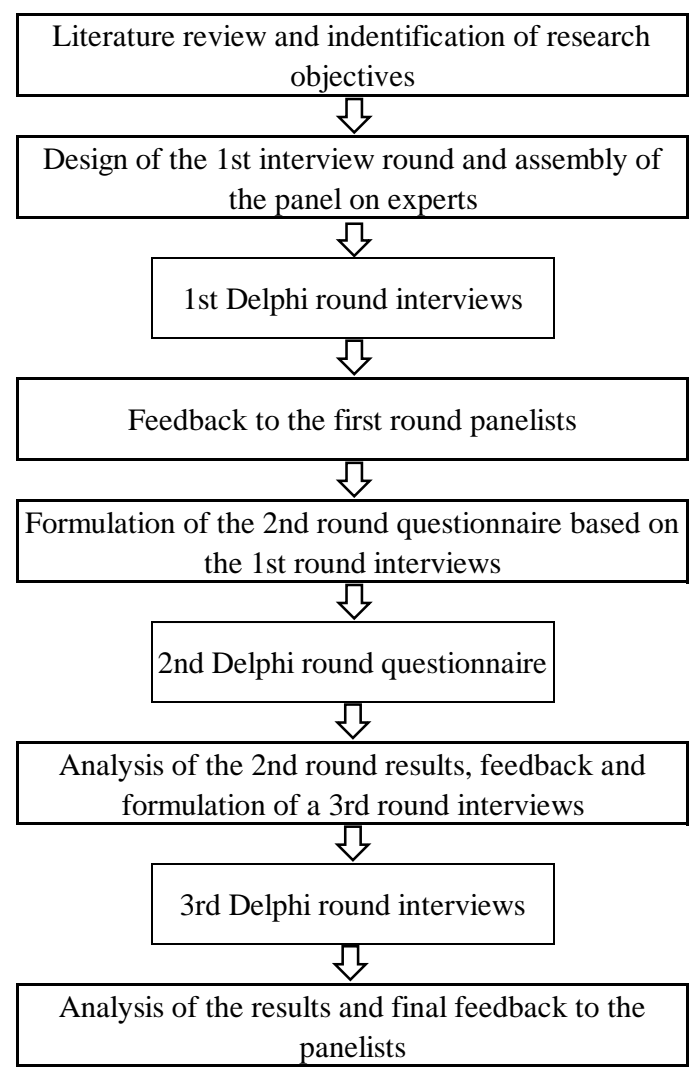

Figure 1. The Delphi process.

In the first round of data collection, the study focused on the structure of the wood construction value chain and cooperation between the parties in this chain. It focused also on the more general market and institutional settings with the interviews therefore covering the overall state of the wood industries, raw material and end-use market issues, but also the role of sustainable development as a concept as such. These themes were included in the interview guide based on literature review and analysed elsewhere (Toppinen et al. 2017). In the second Delphi round, the emphasis was given to the themes and topics that were seen as the most thought provoking or controversial in the first Delphi phase. The questionnaire consisted of 42 closed-ended questions, in which we again focus on business development related items. Thus, the first round interview material was used in the Round 2 in developing more concrete statements, for which their likelihood and desirability could be assessed among the panelists to explore areas where they see the future development could diverge. The data from Round 3, which was built upon on previous rounds, acted to deepen the understanding of particularly the business model development issues. The third round interview data was analysed using qualitative methods, namely thematisation, building on the conceptualization of business model by Osterwalder et al. (2005). All authors were involved in the data analysis during this stage to ensure more reliable interpretation and identification of relevant aspects in a rather fuzzy setting.

Although we did not interview end-users (i.e. residents, consumers), yet, we are able to analyze trough data how experts position customers in business model thinking. For example, in both the first and round interviews there was a question concerning consumer market and how the interviewees recognized needs and changing consumer behavior. 


\section{Results and discussion \\ 4.1 Partner network}

During the first round interviews, it became obvious that the current co-operational schemes (and the future direction of this within WMC business) is a complex and difficult topic to panellists. As a general observation, the most experienced in prior co-operative efforts were those respondents who had experience from working in larger companies. Respondents from smaller wood industry companies were used to working with architects. However, the further upstream the respondents were from the end users, the less they seemed to actively searching for co-operative relationships across the members of construction value network.

What should also be noted, is that the panellists from the building industry were interested in offering their expertise (and in some cases already utilized it) to the solution providers. Networked structures, co-operation with competitors, the standards, complexity and time consuming nature of construction projects, large operators controlling a big part of the value chain, hybrid building, online marketplaces, and even competing ecosystems within the WMC were all mentioned in the interviews. However, this happened with little coherence in place between the respondents, as the following quotes show: "It could be [that in the future] we will see competitors as partners. One manufactures the walls and the other manufactures the flooring." Executive from wood industry, Finland; "It is more and more important to find strategic alliances" Executive from wood industry, Sweden.

Furthermore, the respondents did see co-operation as an important factor in the future, however their views differed widely on how and with whom this co-operation could happen. Smaller, local operators, were more prone to discuss networked models, in which they co-operate with other small operators. The concept of hybrid material building solutions seemed particularly attractive to the panellists. However, the idea of actual co-operation between the wood construction sector and the concrete solution providers was strongly challenged by some respondents. This was partly due to the on-going 'wood vs. concrete' dispute visible in the Nordic region. Examples from respondents illustrate this well: "I don't think the co-operation [with concrete] will happen - there is just too much competition" Executive from wood industry, Sweden; "The way construction has been developed by concrete builders for the past 50 years is not optimal for wood construction. We should get the optimal of our material out." Executive from wood industry, Finland.

Second round data seemed to suggest that there was a strong faith in organizational co-operation between different types of players within the respondents. This happened while the topics that divided the opinions were: "Concrete builders will be significantly more interested in the opportunities offered by wooden building solutions than today", and "By 2030, the amount of companies involved in the wood construction value chain will be much higher than today" (Table 2). Here a partnership model, in which a) construction participants work together as an integrated collaborative team, b) the team has a joint management structure under multi-party contractual arrangements of project partnering, c) the network has an integrated delivery system, this has gained growing interest but has also been used to analyze the Finnish utility construction market (Lahdenperä 2012).

Table 2. Delphi round 2 evaluations of statements related to the configuration of the partner network.

\begin{tabular}{|l|l|l|l|l|}
\hline Id & Statement & & $\begin{array}{l}\text { Likelihood } \\
(\mathbf{\%})\end{array}$ & $\begin{array}{l}\text { Desirability } \\
(\mathbf{\%})\end{array}$ \\
\hline \multirow{3}{*}{9} & $\begin{array}{l}\text { By 2030, strong business networks within the industry will } \\
\text { help us build competitive products more effectively and } \\
\text { faster. }\end{array}$ & Low & 6 & 0 \\
\cline { 3 - 5 } & Medium & 18 & 18 \\
\hline
\end{tabular}




\begin{tabular}{|c|c|c|c|c|}
\hline \multirow{3}{*}{28} & \multirow{3}{*}{$\begin{array}{l}\text { By 2030, concrete builders will be significantly more } \\
\text { interested in the opportunities offered by wooden building } \\
\text { solutions than today. }\end{array}$} & Low & 12 & 0 \\
\hline & & Medium & 35 & 24 \\
\hline & & High & 53 & 76 \\
\hline \multirow{3}{*}{29} & \multirow{3}{*}{$\begin{array}{l}\text { In 2030, the wood construction industry could be described } \\
\text { as a network of specialized organizations of different sizes } \\
\text { rather than a value chain consisting of only a few large } \\
\text { companies. }\end{array}$} & Low & 0 & 0 \\
\hline & & Medium & 65 & 41 \\
\hline & & High & 35 & 59 \\
\hline \multirow{3}{*}{38} & \multirow{3}{*}{$\begin{array}{l}\text { In the future, my organization will co-create value with } \\
\text { different types of players, including customers and } \\
\text { suppliers }\end{array}$} & Low & 0 & 0 \\
\hline & & Medium & 6 & 6 \\
\hline & & High & 94 & 94 \\
\hline \multirow{3}{*}{41} & \multirow{3}{*}{$\begin{array}{l}\text { By 2030, the amount of companies involved in the wood } \\
\text { construction value chain will be much higher than today. }\end{array}$} & Low & 12 & 6 \\
\hline & & Medium & 41 & 35 \\
\hline & & High & 47 & 59 \\
\hline
\end{tabular}

While the SDL perspective was not gauged per se, some of the Delphi round results support the arguments from the theoretical perspective. Especially the content related to (new) networks and related new partners (especially in the group of smaller operators). For instance, the high likelihood and desirability of statement 38 support this conclusion and can be seen to offer support to a value network type of a thinking. The same holds for statement 9 but to a lesser degree. These observations are in line with Vargo and Lusch (2017) that argue that new (service) ecosystems demand new operators based on new social institutions.

The third round saw the panelists emphasizing the need to increase quality and availability of new business solution to WMC. Here, the respondents, voiced hope for getting new players to the market, but also a hope to have more competition among the large-scale construction businesses. In the latter case the respondents also voiced a wish to improve quality of construction per se. What was notable is that our expert panel did not recognize consumers as a part of the WMC business network: they only see companies, NGOs (e.g. Wood Industry Association), and other interest groups (e.g. civil servants) as the key players in the process of developing wood construction businesses.

Yet, they were aware of consumer needs concerning wooden housing, such as builders of one-family houses (using wood as construction material) as well as increasing pro-environmental attitudes among consumers (Holopainen et al. 2014; Luo et al. 2017). The respondents had noticed this consumer values shift towards green consumption: "I think these [voices] valuing nature, decreasing consumption are important, I mean sustainable development and consumption, I would say those issues are guiding consumer choices in the future" Field manager, Finland; "The needs of endusers and fulfilling those ... I think these environmental, I mean the positive influences of wooden material should communicate better [for consumers]" Research manager, Finland; "Wood has a positive image, those green values, wood as good for the health, those kind of things ... greenness is increasing" Technical manager, Finland. Thus, based on these views, addressing end-user sustainability related needs has been realized among industry actors, and in the future, underlining sustainable image of wood could be more emphasized even as a competitive advantage. Especially this is relevant if combined with the earlier comments made by the representatives from smaller companies.

Furthermore, good examples on newly established alliance structures in Finland were brought up. A prime example was the wood-material based new hospital project under construction in north-eastern region of Kainuu. In general, the health benefits from the use of natural building materials and recently much discussed problems with indoor quality in public buildings, were seen as a strong driver 
towards future diffusion of WMC (see also Toppinen et al. 2017). However, at the same time, maintaining cost competitiveness was perceived to be of fundamental importance. Thus, addressing health impacts in industrial construction business with the use of renewal materials seems to be a more an instrumental tool to increase the use of wood than a derivative of an intrinsic motivation towards higher levels of (corporate) sustainability among the value network actors.

\subsection{Capability base}

During the first round of interviews, the development of more sophisticated building solutions was seen as a process demanding financial capital. The respondents saw that only a few of the biggest operators have thus, the necessary resources. Builders, especially the ones that build with a range of different materials, were not interested in developing the solutions, and would rather only be interested in bringing them to the markets once they exist. This is illustrated by the quote: "We will not do this validation [of wood based building solutions], that needs to be undertaken by the wood industry itself." Executive at a building company, Finland. This attitude would seem to indicate a limited interest in taking the role of resource integrator (in line with Vargo and Lusch (2008)). It also limits the propensity by which the smaller contractors can be seen as game changers of WMC and overall uncertainty related to future development of WMC.

Further, the differing timespans, on which operators in the value chain plan their actions, develop their resources, and especially building solutions based on wood, were cited as key issues in cooperation on several accounts. Respondents also identified an issue with the core timespan being the length of a single project: "[Building] processes can be very long, even unbearably so." Research manager at a forestry organization, Finland;

In the second round, the necessary core competencies were approached using the claims listed in Table 3. Based on it, highest conformity exists with the item "... a building process from start to finish will be significantly shorter than today". Statement "Small companies will lack the money and knowhow to develop more competitive and advanced wooden building solutions" was perceived with a low desirability but a higher likelihood to happen. This seems to indicate that there continues to be some scepticism about the ability of SMEs to create a sufficient capability base (see the earlier remark on financial resources). Furthermore, one can see the SDL line of thinking under statement 33 even though here the reactions are somewhat divided. Here the foreseen rise of prefabrication could benefit WMC as the wooden elements are considerably lighter to transport than their concrete counterparts - especially if sustainability criteria are applied to the whole value chain.

Table 3. Delphi round 2 evaluations of statements related to the capability base.

\begin{tabular}{|c|c|c|c|c|}
\hline Id & Statement & & $\begin{array}{l}\text { Likelihood } \\
(\%)\end{array}$ & $\begin{array}{l}\text { Desirability } \\
(\%)\end{array}$ \\
\hline \multirow{3}{*}{8} & \multirow{3}{*}{$\begin{array}{l}\text { By 2030, there will be many experienced professionals both } \\
\text { buying wooden building solutions as well as selling them. }\end{array}$} & Low & 12 & 6 \\
\hline & & Medium & 6 & 18 \\
\hline & & High & 82 & 76 \\
\hline \multirow{3}{*}{31} & \multirow{3}{*}{$\begin{array}{l}\text { Small companies will lack the money and knowhow to } \\
\text { develop more competitive and advanced wooden building } \\
\text { solutions. }\end{array}$} & Low & 18 & 53 \\
\hline & & Medium & 59 & 41 \\
\hline & & High & 24 & 6 \\
\hline \multirow{3}{*}{33} & \multirow{3}{*}{$\begin{array}{l}\text { By 2030, organizational cultures will be more prone to co- } \\
\text { operation and strategic alliances between different } \\
\text { organizations. }\end{array}$} & Low & 0 & 0 \\
\hline & & Medium & 29 & 24 \\
\hline & & High & 71 & 76 \\
\hline \multirow{2}{*}{34} & \multirow{2}{*}{$\begin{array}{l}\text { By 2030, a building process from start to finish will be } \\
\text { significantly shorter than today. }\end{array}$} & Low & 0 & 0 \\
\hline & & Medium & 6 & 18 \\
\hline
\end{tabular}




\begin{tabular}{|l|l|l|l|l|}
\hline & & High & 94 & 82 \\
\hline
\end{tabular}

During recent years, the concrete-based construction industry has faced the problems, such as poor building quality in public buildings. Particularly, difficulties have emerged in humidity control which influences the indoor air quality, but also makes structures prone to the growth of mould. As Luo et al. (2017) noted, the indoor environmental quality (IEQ) has caused increasing public and scientific concern (e.g. eye, nose and throat irritation, headache, breathing problems). Respondents emphasized these challenges existing in the construction business and saw the wooden building as a solution:

"Those increasing needs of customers ... especially these mould problems, people are more and more aware these issues, and there is need for healthier buildings" Executive from building industry, Finland; "As a matter of fact, the most influential things are healthiness of wood, what wood makes to indoor air ... if we can prove those effects better the positive influence of wood" Managing director from wood industry association, Finland.

As Forsythe (2006) has noted, the distrust in the construction industry originates from a changes in construction culture. Earlier the understanding of quality was handed down from the master tradesman to apprentice, and either an on-site builder or possibly a leading hand carpenter generally provided supervision of the work on a full-time basis (Forsythe 2006). Concerning the issues mentioned by Forsythe (2006), in the third round of the Delphi, the availability of skilled personnel was also found to be a bottleneck among some respondents, However, others felt this is not an issue. Thus, further analysis is needed to connect this capability dimension the network and business model issues of WMC.

\subsection{Value configuration}

As the future of the value chain(s), especially how the actors view the operating logic, is the key point of interest in this study, the respondents were faced (Delphi round 2) with a bulk of statements that dig deeper into this logic. The statements, and the reaction to likelihood and desirability of related claims are given in Table 4.

Table 4. Delphi round 2 evaluations of statements related to the value configuration.

\begin{tabular}{|c|c|c|c|c|}
\hline Id & Statement & & $\begin{array}{l}\text { Likelihood } \\
\text { (\%) }\end{array}$ & $\begin{array}{l}\text { Desirability } \\
(\%)\end{array}$ \\
\hline \multirow{3}{*}{5} & \multirow{3}{*}{$\begin{array}{l}\text { By 2030, we will sell and buy more wood construction } \\
\text { products and services through open online platforms, such } \\
\text { as web shops or professional digital networks. }\end{array}$} & Low & 0 & 0 \\
\hline & & Medium & 12 & 29 \\
\hline & & High & 88 & 71 \\
\hline \multirow{3}{*}{10} & \multirow{3}{*}{$\begin{array}{l}\text { By 2030, prefabrication will be the main operating logic, } \\
\text { with less on site building }\end{array}$} & Low & 0 & 6 \\
\hline & & Medium & 0 & 6 \\
\hline & & High & 100 & 88 \\
\hline \multirow{3}{*}{39} & \multirow{3}{*}{$\begin{array}{l}\text { By 2030, we will have more standards, open access } \\
\text { platforms and public data banks for the wood construction } \\
\text { businesses to use. }\end{array}$} & Low & 0 & 0 \\
\hline & & Medium & 24 & 18 \\
\hline & & High & 76 & 82 \\
\hline \multirow{3}{*}{40} & \multirow{3}{*}{$\begin{array}{l}\text { In } 2030 \text {, the best business model is to control a bigger part } \\
\text { of value chain than today. }\end{array}$} & Low & 6 & 12 \\
\hline & & Medium & 59 & 53 \\
\hline & & High & 35 & 35 \\
\hline
\end{tabular}

The panellists indicated highest conformity with the item "By 2030, prefabrication will be the main operating logic, with less on site building". Instead, the item "Best business model is to control a bigger part of value chain than today" divided opinions. This happened both in terms of likelihood 
and desirability and thus, suggests that there is scope for alternative value configuration arrangements, at least in the minds of the experts.

Today's construction industry, having a distinctively project-based mode of networking, could benefit of service-led relationship (SLR) business model. Such a model would solve some of the problems of flawed construction both on the company level, but also on the customer level. Razmdoost and Mills (2016) have noticed that a dark side of relationships found in the project-based construction sector could be solve by emphasising service dominant logic instead of relationship marketing. Scholars suggest that processed-based performance management increases the possibility to intergrade the best available resources to meet the project objectives, and service-led relationship sees the problem solving the main goal of a relationship. Thus, orchestrating value network, where end-users are included, is essential for a firms to build its business model on customer needs in order to be able to recognise customer value and create a business model that will capture it (Pynnönen et al. 2012). As Vargo and Lusch $(2008,7)$ argues "the customer is a co-creator of value, and value is co-produced in networks". Thus, considering, for example, home buyers as one key partner in construction business would bring new understanding on the service offerings. Contrasting, while in small scale private housing projects the end-user is often closely connected to the building process itself, in multistory construction there is an almost total lack of this type of connection.

In order to solve customer problems, and to offer the end-user a valuable service (such as a good quality indoor air custom built interiors, or design) business should strengthen the positive image of wood construction industry. While transforming the business models towards sustainability, the respondents emphasized also price (cost effectiveness), size of a flat, lightness of the wood and swiftness of wooden construction. "In my understanding ... average sizes of flats are decreasing. In today flats are designed for the one or two person" Research manager at a forestry organization, Finland; "I think you are missing the two important competitive factors, lightness and ecological aspects (of wood)" Wood industry sales executive, Finland; "I think reasonable size [a square metre], and reasonable price, I would say in wooden construction we begin with so called expensive and fancy architect houses, it does not serve the idea that we could build a wooden apartment house fast. If we could have prefabricated units ready, storing them in a dry storage facility, and then we quickly build up the house" Executive from building industry, Finland.

\section{Conclusions}

In line with Brege et al. (2014), our study indicates that the key strategic aspects in the WMC business model are related to maintaining cost competitiveness, increasing speed of construction with prefabrication and the enhancing new hybrid material based building solutions. Only to some extent the perceived role of wood is related with wooden buildings as a long-standing carbon stock in combatting climate change. Based on our findings, addressing end-user health impacts in industrial construction business with the use of renewal materials seems to be a key channel for the use of wood. This also happens (possibly - further research is still needed) in the absence of intrinsic motivations towards sustainability among construction business actors.

Addressing health impacts can be aligned with social sustainability dimension for green/sustainable building, which is related with both physical and mental elements (e.g. Strobel et al. 2017, Burnard and Kutnar 2016). Wood has visual-aesthetic value as well. Furthermore, when companies develops sustainable-based business models into more service and user driven orientation, they could combine dimension for green building into green consumption, and eventually provide offerings of green services (e.g measurement of indoor quality) to their customers - and deliver value. 
Issues such as indoor environmental quality (IEQ), fast and green building, could strengthen the image of sustainability and healthiness of wooden material and the implementation of national bioeconomy strategy. From the social equity point of the public sector role can be decisive in terms of proving affordable and social housing, as well as in building better schools, kindergartens or service housing for the elderly people. It could also be decisive in constructing a test-bed (via norms, regulations and innovation policy tools) for new business networks and ecosystems-based trials of new modes of operation.

From the capability viewpoint, our key observations highlight the complementarity of network partner resources as a basis for long-term partnerships among developers, architects, and material providers alike. Therefore, the question arises that which of the network organizations should take the role of resource integrator within the WMC business? In a Swedish study by Brege et al (2014) the picture was seen as being diverse: some firms are capable of doing designer planning by themselves, while new more multi-skilled entrants to the business change the roles and responsibilities in the value network. Therefore, if wooden construction business aims to engage consumers/end-users as a part of their network, firms need to better communicate with wider group of stakeholders through offering new solutions to current problems. Thus, by applying service-led relationship approach to their businesses, firms could develop sustainability driven services for their end-users. Notably, as people do not necessarily buy only tangible object - like a flat - the key criteria are likely to be intangible in the broad sense of service: a good and healthy living solution with reasonable price, possibility to affect the design, and fulfilling the needs of different end-user groups.

Finally, combining, our results seem to demonstrate an arising demand for altering business models towards wood material based multi-story solutions towards the year 2030. However, as with any traditional industry sector, enhancing a stronger sustainability driven culture sustainability driven business models remains a challenge. Furthermore, stimulating collaboration between agile companies, utilizing new market niches (start-ups and SMEs), bringing in the risk-aversive largescale incumbent firms, all this is needed to break free from existing silos - especially needed to set free from concrete dominant regime (Prahalad and Bettis 1986) - in industrial construction business (Hemström et al. 2017).

As a limitation for this study was that our expert panel did not include non-wood construction experts or representatives of end-users. In the future research, there is an urgent need to analyse what kind of changes in the value network are needed to better ensure that the consumers truly are embedded in the co-creation process. Also competition from new players entering the industrial construction market, and collaborative networks between WMC and traditional concrete-based construction businesses belong to the key topics that need to be analysed in more depth. Similar argumentation goes for the formation of project-based alliance business models. Future research is therefore required to elicit especially project level insights on actor values, norms and belief systems of the entire business ecosystem (e.g. Pulkka et al. 2016), and should be targeted to other European countries in which forests and wood materials have scope in promoting implementation of the national bioeconomy strategies.

\section{References:}

Anderson-Connell, L., Ulrich, P. \& Brannon, E. 2002. A consumer-driven model for mass customization in the apparel market. Journal of Fashion Marketing and Management: An International Journal 6 (3): 240-258. 
Bourdeau, L. 1999. Sustainable development and the future of construction: a comparison of visions from various countries. Building Research \& Information 27(6): 354-366.

Bosman, R. \& Rotmans, J. 2016. Transition Governance towards a Bioeconomy: A Comparison of Finland and the Netherlands. Sustainability 8: 1017.

Brege, S., Stehn, L., and Nord, T. 2014. Business models in industrialized building of multi-storey houses. Construction Management and Economics 32: 208-226

Burnard, M. and Kutnar, A. 2015. Wood and human stress in the built indoor environment: a review. Wood Science and Technology 49(5): 969-986

Chandler, J. \& Vargo, S. 2011. Contextualization and value-in-context: How context frames exchange. Marketing Theory 11(1):35-49.

Darko, A., Zhang, C. \& Chan, A. 2017. Drivers for green building: A review of empirical studies. Habitat International, 60, 34-49.

Edvardsson, B., Tronvol, B., \& Gruber, T. 2011. Expanding the understanding of service exchange and value co-creation: a social construction approach. Journal of the Academy of Marketing Science 39(2): 327-329.

Forsythe, P. 2006. Consumer-perceived appearance tolerances in construction quality management, Engineering, Construction and Architectural Management 13(3): 307-318.

Gold, S. \& Rubik, F. 2009. Consumer attitudes towards timber as a construction material and towards timber frame houses - selected findings of a representative survey among the German population. Journal of Cleaner Production 17: 303-309.

Hansen, E. 2016. Responding to the Bioeconomy: Business Model Innovation in the Forest Sector. In Kutnar, A. \& Muthi, S. (eds.): Environmental Impacts of Traditional and Innovative Forest-Based Bioproducts. Springer. p. 227-248

Harris, M. \& Halkett, R. 2007. Hidden Innovation: How Innovation Happens In Six 'Low Innovation' Sectors, National Endowment for Science, Technology and the Arts, London.

Hemström, K., Gustavsson, L. \& Mahapatra, K. 2017. The sociotechnical regime and Swedish contractor perceptions of structural frames. Construction Management and Economics 35: 184-195.

Hoibo, O., Hansen, E. and Nybakk, E. 2015. Building material preferences with a focus on wood in urban housing: durability and environmental impacts. Canadian Journal of Forest Research 45(11): 1617-1627.

Hoffman, A. J., \& Henn, R. 2008. Overcoming the social and psychological barriers to green building. Organization \& Environment 21(4): 390-419.

Holopainen, J., Häyrinen, L. and Toppinen, A. 2014. Consumer value dimensions for sustainable wood products: results from the Finnish retail sector. Scandinavian Journal of Forest Research 29(4): 378-385 
Hu, H., Geertman, S. \& Hooimeijer, P. 2013. The willingness to pay for green apartments: The case of Nanjing, China. Urban Studies 51(16): 3459-3478.

Häkkinen, T. \& Belloni, K. 2011. Barriers and drivers for sustainable building. Building Research \& Information 39(3). 239- 255.

Höök, M., Stehn, L. \& Brege, S. 2015. The development of a portfolio of business models: a longitudinal case study of a building material company. Construction Management and Economics 33(5-6): 334-348.

Killip, G. 2013. Products, practices and processes: exploring the innovation potential for low-carbon housing refurbishment among small and medium-sized enterprises (SMEs) in the UK construction industry. Energy Policy 62: 522-530.

Lahdenperä, P. 2012. Making sense of the multi-party contractual arrangements of project partnering, project alliancing and integrated project delivery. Construction Management and Economics 30(1): $57-79$.

Landeta, J. 2006. Current validity of the Delphi method in social sciences. Technological Forecasting \& Social Change 73(5): 467-482.

Lessing, J. \& Brege, S. 2015. Business models for product-oriented house-building companies experience from two Swedish case studies. Construction Innovation 15(4): 449-472.

Luo, W., Kanzaki, M., \& Matsushita, K. 2017. Promoting green buildings: Do Chinese consumers care about green building enhancements? International Journal of Consumer Studies. Forthcoming.

Osterwalder, A., Pigner, Y. \& Tucci, C. 2005. Clarifying Business Models: Origins, Present, and Future of the Concept. Communications of the Association for Information Systems. Vol 16:1.

Payne, A., Storbacka, K. \& Frow, P. 2008. Managing the co-creation of value. Journal of the Academy of Marketing Science 36(1):83-96.

Pulkka, L., Ristimäki, M., Rajakallio, K. \& Junnila, S. 2016. Applicability and benefits of the ecosystem concept in the construction industry. Construction Management \& Economics 34(2): 129144.

Magretta, J. 2002. Why Business Models Matter. Harvard Business Review 80(5): 86-92.

Mokhlesian, S. \& Holmen, M. 2012. Business model changes and green construction processes. Construction Management and Economics 30: 761-775.

Pelli, P. 2016. Service ecosystems as frameworks to elaborate sustainable futures. Proceedings of $26^{\text {th }}$ RESER Conference. September 8th-10th, 2016, Naples, Italy.

Pels, J., \& Sheth, J. N. 2017. Business models to serve low-income consumers in emerging markets. Marketing Theory, http://journals.sagepub.com/doi/abs/10.1177/1470593117704262.

Prahalad, C. K., \& Bettis R. A. 1986. The dominant logic: A new linkage between diversity and performance. Strategic Management Journal 7 (6): 485-501. 
Pynnönen, M. 2008. Customer driven business model-connecting customer value to firm resources in ICT value networks. Dissertation, Acta Universitatis Lappeenrantaensis. Lappeenranta University of Technology.

Pynnönen, M., Hallikas, J. \& Ritala, P. 2012. Managing customer-driven business model innovation. International Journal of Innovation Management 16 (4): 1250022.

Razmdoost, K \& Mills, G. 2016. Towards a service-led relationship in project-based firms, Construction Management and Economics, 34:4-5, 317-334, DOI: 10.1080/01446193.2016.1200106.

Teece, D. 2010. Business model, business strategy and innovation. Long Range Planning 43(2-3): 172-194.

Toppinen, A., Wan, M. \& Lähtinen, K. 2013. Strategic orientations in global forest industry. Book Chapter 17 in Hansen, E. et al. (Eds.): Global Forest Industry: Changes, Practices and Prospects. Taylor \& Francis Ltd.

Toppinen, A., Röhr, A., Pätäri, S., Lähtinen, K. \& Toivonen, R. 2017. The future of wooden multistory construction in the forest bioeconomy - a Delphi study from Finland and Sweden. Journal of Forest Economics (in press).

http://www.sciencedirect.com/science/article/pii/S1104689916300952.

Storbacka, K., Frow, P., Nenonen, S., \& Payne, A. 2012. Designing business models for value cocreation. Review of Marketing Research 9:51-78.

Strobel, K., Nyrud, A. \& Bysheim, K. 2017. Interior wood use: linking user perceptions to physical properties. Scandinavian Journal of Forest Research, DOI:10.1080/02827581.2017.1287299

Vargo, S. \& Lusch, R. 2004. Evolving into a New Dominant Logic for Marketing. Journal of Marketing 68: 1-17.

Vargo, S. \& Lusch, R. 2008. Service-dominant logic: continuing the evolution. Journal of the Academy of Marketing Science 36(1):1-10.

Vargo, S. \& Lusch, R. 2016. Institutions and axioms: an extension and update of service-dominant logic. Juornal of the Academy of Marketing Science 44:5-23.

Vargo, S. \& Lusch, R. 2016. Service-dominant logic 2025. International Journal of Marketing Research, in press. http://dx.doi.org/10.1016/j.iresmar.2016.11.001.

Vargo, Stephen L., 2007. On Theory of Markets and Marketing: From Positively Normative to Normatively Positive. Australasian Marketing Journal 15(1):53-60.

Wang, L., Toppinen, A., and Juslin, H. 2014. Use of wood in green building: A study of expert perspectives from the UK. Journal of Cleaner Production 65: 350-361. 
Appendix. Composition of the Delphi panel with their professional backgrounds and participation in the different stages of data collection.

\begin{tabular}{|c|c|c|c|c|c|}
\hline Country & Gender & $\begin{array}{c}\text { Years of prof. } \\
\text { experience }\end{array}$ & Title & Organization type & $\begin{array}{c}\text { Participation in } \\
\text { rounds }\end{array}$ \\
\hline Finland & Male & 14 & Senior vice president & Wood industry & $1-3$ \\
\hline Finland & Female & 22 & Director of CSR & Wood industry & 1 and 2 \\
\hline Finland & Male & 31 & Managing director & Forestry & $1-3$ \\
\hline Finland & Female & 1 & Executive & Building industry & $1-3$ \\
\hline Finland & Male & 16 & Owner & Forestry & 1 and 2 \\
\hline Finland & Male & 15 & Research manager & Forestry & $1-3$ \\
\hline Finland & Male & 3 & Field manager & Forestry & $1-3$ \\
\hline Finland & Male & 26 & Production director & Building industry & $1-3$ \\
\hline Finland & Male & 5 & Senior vice president & Wood industry & 1 and 2 \\
\hline Finland & Male & 22 & Sales executive & Wood industry & $1-3$ \\
\hline Finland & Female & 16 & Planning executive & Building Industry & $1-3$ \\
\hline Finland & Male & 23 & Managing director & Wood ind. association & 1,3 \\
\hline Finland & Male & 15 & Senior advisor & Public sector & 3 \\
\hline Finland & Male & 12 & Technical manager & Building industry & 3 \\
\hline Sweden & Male & 21 & Senior advisor & Forestry & 1 and 2 \\
\hline Sweden & Male & 15 & Managing director & Wood industry & $1-3$ \\
\hline Sweden & Male & 11 & Managing director & Wood industry & $2-3$ \\
\hline Sweden & Male & 11 & President & Wood industry & 1 \\
\hline Sweden & Male & 17 & Vice pres. market dev. & Forestry & 1 and 2 \\
\hline Sweden & Male & 12 & Academic expert & Building ind. expert & $1-3$ \\
\hline Sweden & Male & 8 & Sales manager & Wood industry & 1 and 2 \\
\hline Sweden & Male & 15 & Academic expert & Building ind. expert & 3 \\
\hline Sweden & Female & 10 & Managing director & Public sector & 3 \\
\hline
\end{tabular}

